\author{
John Christopher Sikorski \\ University of Notre Dame, IN, USA
}

\title{
The Hinge of Salvation: Body, Liturgy, and Bioethics
}

\begin{abstract}
Dominant trends within the philosophical debate over personhood and identity tend to discount the significance and meaning of the human body and often slip into dualistic conceptions. I will argue that a Catholic theology of the body challenges many of the prevalent understandings in bioethics today. Such a notion takes Christ's Incarnation as its foundation and seeks to develop an account of the human body in the context of the call to communion imprinted on humanity as made in the image of the Trinitarian communion of love. Such a conception counteracts forms of utilitarian or technological reductionism of the person. While Catholic bioethicists will need to consider how such an account will have practical applicability to cases, the call to communion ought to be fostered through the liturgical life of the Church, which enables Catholic bioethicists to develop a liturgical worldview that guards against devaluations of the dignity of the human person.
\end{abstract}

\section{Keywords}

Person, body, communion of persons, John Paul II, liturgy, sacraments, Christian anthropology, dualism, utilitarianism, Incarnation, sacramentality, theology of the body, ritual.

"The truth is that only in the mystery of the incarnate Word does the mystery of man take on light... Christ... fully reveals man to himself and makes his supreme calling clear"'. While this Christological-anthropological affirmation of the Second Vatican Council is one of the most frequently cited conciliar passages within the recent magisterial documents of the Church, it is difficult to perceive how it might immediately be applied to the field of bioethics. However, a fundamental issue underlying many contemporary

1 Gaudium et Spes 22; A. Flannery O.P., (ed.), New York, 1998, Costello Publishing Company. All citations given will be from this translation. 
medical and bioethical debates is the nature and status of the human person"2. The bioethicists, philosophers, legal scholars, and theologians involved in the personhood debate identify personhood in several key ways, definitions which are themselves based on anthropological presuppositions, assumptions about the role, scope and limits of technology, or the function of deliberative processes in pluralistic societies. Missing from many contemporary notions of personhood is an adequate account and understanding of the role, purpose, and meaning of the body.

In this paper, I will begin by indicating several dominant non-Catholic voices within the historical personhood debate in the United States. Since the views of these authors are of central importance, it will be necessary to briefly summarize their views, in order to inquire about how a Catholic conception of the human person might contribute to what is found lacking. It will be evident that dualistic underpinnings of these conceptions of personhood are the result of the larger framework of "technological utopianism" that underlies the "Baconian project" 3 . I will argue that a Catholic theology of the body challenges many of these prevailing notions by pointing to the significance and meaning of the human body as revelatory of the person. Such a notion takes Christ's Incarnation as its foundation, and seeks to uphold a communion of human persons created in and called to imitate the Trinitarian love of God. Finally, this communion marked by solidarity and openness in all human relationships ought to be fostered through the liturgical life of the Church, which enables Catholics to develop a liturgical worldview that guards against devaluations of the dignity of the human person, and which provides for Catholic bioethicists a locus of formation from which to articulate their own positions.

\section{Personhood and Human Dignity or Sacredness}

In his article, "Four Indicators of Humanhood - the Inquiry Matures", the American bioethicist Joseph F. Fletcher provides an analysis of several

2 Thus, the fundamental definition of personhood will affect concrete discussions of abortion, embryonic research and experimentation, gene therapy and genetic manipulation, cloning, care for the elderly, the physician-patient relationship, etc.

3 For a thorough discussion of the "Baconian project" see G. McKenny, To Relieve the Human Condition: Bioethics, Medicine, and the Body, Albany 1997, SUNY Press. 
prevailing notions of personhood"4. On the one hand, three notions of personhood which are analyzed identify the notion of personhood by placing primary importance on a particular time, phenomenon, or experience. Opposed to any of these views stands the "biological species" view, offered by William E. May, in which personhood is determined by "virtue of who we are [as members of the human species], and not by what we achieve or do"s. While articulating differing opinions, all of these scholars are united in their desire to define personhood, recognizing that once personhood is established, such a definition would have an impact on concrete practices and judgments that can be made regarding actions, treatments, manipulations, and services that might be performed to or upon a particular being. There is a recognition that personhood, however it is defined, carries with it a (however weak or unspecified) notion of respect, dignity, value, or sacredness.

The American legal theorist and philosopher, Ronald Dworkin, makes an important contribution to the discussion about the notions of "sacredness" or "dignity" in our modern culture, by noticing that a majority of people in a pluralistic society would agree, regardless of their radically differing fundamental moral systems, that the "life of a human organism has intrinsic value in any form it takes, even in the extremely undeveloped form of an early, just-implanted embryo". Something can have "intrinsic value" due to the fact that it is "incrementally valuable" (the more of it we have the better), and that which is "sacred or inviolable". Something is "sacred", regardless of what people happen to "enjoy or want or need," and this is the kind of value

4 See J. Fletcher, Four Indicators of Humanhood - The Inquiry Matures. "Hastings Center Report" 4 (December 1975): pp. 4-7. He compares and contrasts the "self-awareness" notion of Michael Tooley, in which "the real precondition for having a serious right to life...[is] subjectivity or self-awareness." Secondly, Fletcher presents Richard McCormick's "human relationality" theory in which "life is a value to be preserved insofar as it contains some potentiality for human relationships", since the "meaning, substance, and consummation of life is found in human relationships". Third, the "moral happiness" criterion offered by an anonymous pediatrician at the Texas Medical Center distinguishes between moral and biological humanity, and places an emphasis on the person associated with the ability to express "affectionate responses" and a state of "constant euphoria," as might be seen in a child with mental retardation who is, by all counts, "happy". Fletcher finally presents his own "neo-cortical" indicator that defines personhood as the point at which the "cerebral cortex" begins to "synthesize". There is no "person" without this synthesis, "no matter how much the individual's brain stem and mid-brain may continue to provide feelings and regulate autonomic physical functions".

5 Ibid., p. 378.

6 R. Dworkin, Life's Dominion: An Argument about Abortion, Euthanasia, and Individual Freedom, New York 1993, Alfred A. Knopf, p. 69. 
which most people would assign to human life. Even something considered "sacred" by most, however, can still be either "incrementally valuable" or "selectively valuable." When judging the sacred value of human life, we perceive each human life as a though we might perceive a work of nature and of art, as well as the "product of deliberate human creative force" such as the life experiences that have shaped an individual"7.

Having laid out his categories, Dworkin concludes, "The life of a single human organism commands respect and protection, then, no matter in what form or shape, because of the complex creative investment it represents and because of our wonder at the divine or evolutionary processes that produce new lives from old ones, at the processes of nation and community and language through which a human being will come to absorb and continue hundreds of generations and cultures and forms of life and value, and finally, when mental life has begun and flourishes, at the process of internal personal creation and judgment by which a person will make and remake himself, a mysterious, inescapable process in which we each participate, and which is therefore the most powerful and inevitable source of empathy and communion we have with every other creature who faces the same frightening challenge"s.

At first glance, a Catholic theologian committed to the sacred inviolability of all human life might agree with Dworkin that human life, in whatever form, has an intrinsic value and sacredness that lies outside of itself. However, Dworkin proceeds with a social analysis of commonly held positions by both "conservatives" and "liberals" (in American society) to show that the application of his theory of "sacredness" can be very difficult, especially in the "test case" of abortion. For example, with regard to abortion, "conservatives" generally make exceptions in the cases of rape, incest, or a threat to the health or life of the mother, while "liberals" tend to place more emphasis on the freedom and right of the mother to both exert control over her body and to not be burdened by an objectively difficult situation that might come about as a result of carrying through with the pregnancy. Where somebody draws the line depends on whether one accepts the greater relative value of life as a "natural investment" (conservatives) or life as a "creative investment"

\footnotetext{
7 Ibid., p. 82.

8 Ibid., p. 84.
} 
(liberals) ${ }^{9}$. Dworkin characterizes "conservatives" as holding that there are possible exceptions to the prohibition on abortion, which leads him (rightly) to point out that conservatives would not make exceptions if "the fetus were a person with rights and interests of its own, because that person would be completely innocent whatever the nature or level of its mothers' guilt"10.

It becomes apparent that Dworkin's social analysis of the issue of abortion, and the related categories of judging the sacredness of human life based on its natural or creative "investments," lacks a strong notion of personhood. He notices that neither liberals nor conservatives seem to cling to a consistent understanding of the person, and hence the various degrees of "exceptions" based on a relative balance of the natural or creative investments. "So we have no formulas for actual decision but only, at best, a schema for understanding the arguments and decisions that we and other people make in real life. I have argued that we do badly, in understanding and evaluating these decisions and arguments, if we try to match them with procrustrean assumptions about fetal personhood and rights. We do better to see them as reflecting more nuanced and individual judgments about how and why human life is sacred, and about which decision of life and death, in all the concrete circumstances, most respects what is really important about life"

The Catholic bioethicist would agree with Dworkin in many regards, including a notion of the "intrinsic" value and sanctity of life, but would take issue with his first principles. Underlying his analysis is a rejection of

9 Interestingly, Dworkin dismisses those who might hold that abortion is wrong without any exceptions by calling this an "extreme position" which is accepted only by a "small minority of devout Catholics" or "fundamentalists". It is important to notice that this position is labeled "extreme", rather than the "very conservative" characterization given to those who would hold that abortion is only acceptable in cases of rape, incest, or the life of the mother. One might ask whether Dworkin, in his analysis of a "spectrum" of opinions, is doing justice to a position that seems to play an increasingly important role in debates today: Is the "consistent ethic of life" upheld by the Catholic Church, which includes this "extreme" position on abortion, simply a radical, fringe opinion that might be discounted as easily as Dworkin seems to assume? Is there not, perhaps, a logic operative within it that would seem to go far in explaining the "inconsistencies" and "lack of agreement" within the various parties as to the status of the person? That is, Dworkin (correctly) notices that "conservatives" reject abortion on the whole, but seem to allow exceptions; these "exceptions" cannot indicate that the position has an underlying, unqualified, and uniform respect for all human life. (If it did, then they would not allow for any exceptions). Might the "extreme" Catholic position provide the consistency that Dworkin seeks, however "extreme" it might seem?

${ }^{10}$ Ibid., p. 97.

${ }^{11}$ Ibid., p. 100. 
the notion of fetal personhood, or treating the fetus as if it were a person with a fullness of rights. Based on his "phenomenological" social analysis, this conclusion might be justified as a result of the prevailing attitudes in modern American society. But what would happen to Dworkin's argument if social attitudes suddenly changed? What if a society commonly accepted that abortion is wrong in all situations, with no exceptions? Would his analysis of life's sacredness based on a balance of the creative and natural investments still hold? It seems that Dworkin's analysis needs a more specified notion of personhood, and need not too quickly assume that there is a "common morality" that all might agree upon.

The American philosopher, Bonnie Steinbock, suggests a more robust notion of personhood as necessary for an understanding of the respect that ought to be shown to human life. In a discussion of the "respect" due to embryos, Steinbock seeks to define personhood in a manner that would uphold Dworkin's "implicit sacredness" without relying as much on the subjective notions present in a given society. First, she rejects a notion of personhood that she identifies as the "species or genetic humanity view," which "holds that human embryos are human beings, just like you and me. They have all the rights of human beings, including the right to life and a general Kantian right not to be used as 'mere means' to others' ends"12. She sees within such an approach a confusion of biological and moral personhood, and indicates that the view seems to arbitrarily link personhood with a particular species. "Why should moral status, rights, and the like be limited only to human beings, that is, members of the species homo sapiens? Is it not possible that there are non-humans, such as intelligent extraterrestrials, who (if they exist) would be entitled to equal respect and rights?"13.

The necessary defining factor of personhood, according to Steinbock, ought to take into account sentience and an "identity theory of consciousness". She calls this theory, which accounts for a complicated interplay of factors, the "interest view, which "links moral status to interests and restricts interests to sentient beings"14. In this view, unless a being has a "conscious awareness of some kind, a being does not have a life to lose". However, the case of patients in persistent vegetative states is not excluded from this view, as the

12 B. Steinbock, Respect for Human Embryos, in: Cloning and the Future of the Human Embryo, P. Lauritzin (ed.), Oxford 2001, Oxford University Press, p. 21.

13 Ibid., p. 21.

${ }^{14}$ Ibid., p. 23. 
"person who is now unconscious has had a set of beliefs, desires, and interests that are compounded out of these beliefs and desires"15. Based on this theory of personhood, Steinbock notices that embryos (at least pre-implantation) do not have a "life to lose" as they "cannot feel, pain, be hurt, or made to suffer", and there can therefore be no identification between an adult person and early gestation fetuses and embryos, since they have no experiences that could contribute to shaping their personality. Steinbock therefore agrees with Dworkin in noticing that it is important to respect the human embryo, and agrees that people might differ with regard to the nature of this respect, and so she adopts a minimal position which posits that "our only hope is to formulate, as precisely as possible, our views on these symbolic, intangible issues and to listen carefully to those who have opposing views"16.

From the above analysis of representatives of central positions in the "personhood debate", there is a clear consensus that human life is sacred and has a dignity that is inviolable, although the sacredness and inviolability is often determined by the underlying notion of personhood that one holds. Of the above authors, only William E. May does not reject a definition of biological personhood, and as a Catholic moral theologian, represents a particular instantiation of the doctrine held by the Catholic Church. As Steinbock notices, the attitudes of the Catholic Church make sense "only if one thinks of the pre-implantation embryos as human persons who deserve the same respect in death as any other person"17.

\section{A Lingering Dualism?}

A common characteristic of many of the above non-Catholic personhood definitions is a potentially dualistic underpinning. On what basis ought we to make decisions about personhood? Are they arbitrary decisions that

${ }^{15}$ Ibid., pp. 23-25.

${ }^{16}$ Ibid., p. 33. We can therefore see that both Dworkin's and Steinbock's views are deeply wedded to the assumptions underlying the liberal, democratic process. Society is assumed to be pluralistic and possessing many moral disagreements, and since truth cannot be agreed upon objectively, recourse is made to pragmatic and phenomenological discussions focused on both reasonably held positions and social experience, and these play a large role in determining the concrete norms which ought to be adopted and applied.

${ }^{17}$ Ibid., p. 31. 
determine personhood based simply on moral, relational, biological, or mental qualities? What role might the body and embodiment play in such discussions? The notions of personhood suggested in this analysis seem to result from a body-soul, or body-person, dualism that falls within the larger scope of the "Baconian project", or the "technological utopianism" that characterizes the state of much of bioethics and medicine today.

The Catholic moral theologian Lisa Cahill notices that "modern science tends to build a strictly material body, and locates the causes of its illness and health in material causes, tending thereby to erode both the interdependence of the spiritual and psychological states, and the connectedness of the embodied self with other elements and presences in the cosmos"18. A loss of the vision of the person, integrally and adequately considered as a compositum humanum, has led to the "reign of informed-consent" in bioethics today, which is a natural result of the self that is defined as an "autonomous, private, and self-constituting will"19. Such a view, which often results from a separation of "personhood" from "human being" and an instrumentalization of the body as a mere "mechanism" or "part" of the person, when adopted by either doctors, scientists, or bioethicists, can lead to the degradation and denigration of a person or a particular group of people.

Many identify these prevailing views in bioethics, the scientific community, and medicine today as a result of the "Baconian project", characterized by the manipulation of nature to serve humanity's ends. In this project, faith is placed in science and "progress", which is understood as the "triumph of humanity over "nature""20. The American Protestant ethicist Gerald McKenny notes the origins of such a view in early modernity, particularly in the philosophies of René Descartes and Francis Bacon. "Descartes inaugurates the process that will... render the mastery of the seeing eye and the intervening hand, while also distancing the essential person, the soul, from the body that, despite the power of medicine, is destined to decay and die"21. The body-soul dualism of Descartes and his followers reduces the body to a machine which is seen as a "property of the 'person' and the instrument of his desires and preferences" 22.

${ }^{18}$ L. Cahill, Embodiment and Moral Critique: A Christian Social Perspective, in: Embodiment, Morality, and Medicine, L.S. Cahill, M.A. Farley (eds.), Dordrecht 1995, Kluwer Academic Publishers. See On Moral Medicine, p. 402.

19 Ibid., p. 404.

${ }^{20}$ Pope Benedict XVI, Spe salvi, 17.

${ }^{21}$ G. McKenny, To Relieve the Human Condition, Albany 1997, SUNY Press, p. 192.

22 Ibid., p. 198. 
McKenny traces the development of Cartesian dualism to show how modern medicine and bioethics is characterized by a shift away from "the body as object of spiritual and moral practices" to an understanding of the body as "object of practices of technological control"23. Debates in bioethics today, which often seem to be intractable disputes among parties, could be enriched by countering the dominant technological, dualistic approach to the body. This attempt ought to be made by becoming "aware of the attitudes and practices that have formed us in connection with the technological control of medicine over our bodies and to determine which attitudes and practices should form us - whether those of modern societies or some others" 24 .

Lutheran ethicist Gilbert Meilaender agrees with McKenny on the necessity to reflect upon the attitudes and practices that might serve as a foundation for more fruitful bioethical reflection. "Do we need a moral theory to guide our bioethical reflection, or can we make our way from case to case, gradually mapping the territory?"25. By reflecting on the limits of such methods as "principlism," Meilaender proposes an “'integration' of medical ethics and universal morality within a community (or communities) in which there is agreement not just on a few general principles but on the meaning of the good life" ${ }^{26}$. Only when there is an agreement on the fundamental meaning of the nature of human life, can there be fruitful dialogue about specific issues and cases, beneath which lie the "deepest matters of humanity"27.

Both McKenny and Meilaender suggest that the Christian community and theological tradition can provide an alternative conception of the person, and the associated nature, meaning, and purpose of the human body, in order to enhance dialogue within the bioethical community. Bioethics and the shaping of public policy will need "inviting back 'those alternative imaginations' that religious communities and theological traditions provide" 28 . Within the Christian tradition, one can find an appreciation of the body and its meaning that might effectively contribute to a discussion in the attempt to move

${ }^{23}$ Ibid., p. 21.

${ }^{24}$ Ibid., p. 217.

${ }^{25}$ G.C. Meilaender, Body, Soul, and Bioethics. Notre Dame, IN, 1995, University of Notre Dame Press, p. 2.

${ }^{26}$ Ibid., p. 8.

${ }^{27}$ Leon Kass, as quoted in Meilaender, p. 36.

${ }^{28}$ Ibid., p. 33. Perhaps Meilaender and Steinbock would agree here, as Steinbock has noted the importance of listening to diverse and opposing views (see above). 
beyond the dualism inherent in some modern manifestations of the "Baconian project". "It is... necessary to offer... a description of Christian discourse and practices regarding the body that is capable of resisting and appropriating technological control of the body... and the limits we should observe in improving our bodies and eliminating suffering" 29 . As Cahill notices, over the course of the Catholic tradition, one finds (although with some notable exceptions) the "anti-dualism" about the body that is rooted in the Gospels. "God's reign is realized in the life and ministry of a man formed bodily in the womb of a woman, a man who in his very walking, sleeping, eating, drinking, talking, touching, fasting, night-watching, pain and death makes present the compassion of God for human suffering" ${ }^{30}$. Such a worldview tends toward integration rather than dualism, affirmation of the body and the person, rather than denigration, and freedom rather than control ${ }^{31}$.

In order to uphold robust notions of personhood and provide the elements lacking in conceptions summarized by Fletcher, Dworkin, or Steinbock, whose positions assume body-soul or body-person dualism in one form or another, the task for the Catholic bioethicist is two-fold. Catholic bioethicists must develop and more adequately understand their own theology of the body, as Catholic discourse has not always been immune to the dualism inherent in some strands of modern discourse. Secondly, Catholics, formed in their own theological understanding of the body, must be able to make philosophical arguments in the public square which are formed by the worldview offered by theology reflecting on revelation.

\section{The Body: Integrated, Self-Giving, Revelatory}

Having examined the deficiencies of some current notions of personhood, resulting from the tendency in modern bioethics to separate a discussion of personhood from the discussion of the body, and an inquiry into the nature of the body as such, it is necessary to turn to a "theology of the body" that can provide one example of a "discourse... that is capable of resisting and

\footnotetext{
${ }^{29}$ G. McKenny, To Relieve the Human Condition, Albany 1997, SUNY Press, p. 219.

${ }^{30}$ L. Cahill, Embodiment and Moral Critique: A Christian Social Perspective, p. 402.

${ }^{31}$ Ibid., p. 405.
} 
appropriating technological control of the body" ${ }^{\prime 32}$. This discussion will draw from Catholic sources, and cannot therefore be addressed directly to secular philosophers and bioethicists. However, an Incarnational "theology of the body" sustained by the liturgical life and worldview of the Church can provide a necessary locus of formation within which Catholic bioethicists can develop an integral vision of the person, including the body, and from which they can begin to develop philosophical reflections and arguments that can be addressed to the secular sphere.

In beginning to sketch a Catholic theology of the body, it is important to recall the plurality of "theologies of the body" in the tradition ${ }^{33}$. I will limit my discussion to Pope John Paul II's one hundred twenty nine catecheses, Man and Women He Created Them, since there have been several recent attempts to evaluate and relate these catecheses to bioethics ${ }^{34}$. It is important to begin by noticing that John Paul II did not intend these catecheses to be directly related to the field of bioethics. As David Bentley Hart points out, John Paul II's "theology of the body" does not "offer discrete logical propositions or policy recommendations" that might be extracted from the larger context of his teachings so as to "advance the conversation" or "suggest a middle course" or "clarify ethical ambiguities" 35 . Robert Jenson also agrees that there are not "many explicit answers to particular bioethical problems"36. Hart suggests rather that at the "heart of its anthropology is a complete rejection - one might almost say, ignorance - of any dualism between flesh and spirit" ${ }^{37}$.

${ }^{32}$ G. McKenny, To Relieve the Human Condition, Albany 1997, SUNY Press, p. 219.

${ }^{33}$ The literature is vast, and it is, of course, beyond of the scope of this paper to provide a survey of theological approaches to the body in the Christian tradition. Some theological methods might include Christological theologies of the body, feminist theologies of the body and embodiment, phenomenological theologies of the body, sociological theologies of the body, etc. $C f$. B. Ashley, Theologies of the Body: Humanist and Christian, Braintree, MA, 1995, The Pope John Center. P. Brown, The Body in Society: Men, Women, and Sexual Renunciation in Early Christianity, New York 1998, Columbia University Press. A. Vogel, Body Theology: God's Presence in Man's World, New York 1973, Harper and Row.

${ }^{34} C f$. R.W. Jenson, Reading the Body, The New Atlantis, (Summer 2005): 73-82. D.B. Hart, The Anti-Theology of the Body, The New Atlantis (Summer 2005), p. 64-73. M.F. Rousseau, Deriving Bioethical Norms from the Theology of the Body, in: National Catholic Bioethics Quarterly (Spring 2003), pp. 59-67.

${ }^{35}$ D.B. Hart, The Anti-Theology of the Body, The New Atlantis (Summer 2005), p. 65.

${ }^{36}$ R.W. Jenson, Reading the Body, The New Atlantis, (Summer 2005), p. 73.

${ }^{37}$ D.B. Hart, The Anti-Theology of the Body, The New Atlantis (Summer 2005), p. 66. 
John Paul II begins each section of his series of reflections with the words of Christ in the Gospels, particularly Christ's encounters with different groups of interlocutors such as the Pharisees and the Sadducees, as well as with the writings of St. Paul. From his analysis of these sections of the New Testament, he argues that "the Christian ethos is characterized by a..."communion of persons", which is the deepest substratum of human ethics and culture. While for the Manichean mentality, the body and sexuality constitute, so to speak, an "anti-value", for Christianity, on the contrary, they always "remain a value not sufficiently appreciated" 38 .

Rather than condemning or denigrating the body, or emphasizing the spiritual over the physical, the Catholic tradition upholds a vision of the person, considered in her proper integrity and fullness. "The Manichean way of understanding and evaluating man's body and sexuality is essentially foreign to the Gospel; it does not conform to the exact meaning of the words in the Sermon on the Mount pronounced by Christ" 39 . Having begun with the words and encounters of Christ, John Paul II uses Christ's reference to "the beginning" in his discussion with the Pharisees regarding divorce, and sees this as Christ's reference to the creation of man and woman in the first two chapters of the book of Genesis ${ }^{40}$. He therefore begins with an analysis of the human condition according to God's "original plan of creation," in which the human person was created in a state of body-soul integrity, and the temptation of treating another with a utilitarian attitude was not present ${ }^{41}$. He identifies four notions as characteristic of the prelapsarian state: original solitude, original unity, original innocence, and original nakedness, which he develops through phenomenological or "psychological" cross-readings of the

${ }^{38}$ Man and Woman, 45:3. L. Cahill also shows how the affirmative Christian ethos of the body is present in Christianity, not only in the New Testament, but also through the examples of the Church Fathers and medieval women mystics. "Christianity has been neither intransigently dualistic nor negative about the body. They [these figures in the tradition] also indicate that a positive, integrated approach to the body and soul, or body and mind, need not exclude - indeed may depend on - an ordering of the body related to a social vision... Christianity both channels a social vision through the body, and defines community partly in terms of bodily experiences and roles”. L. Cahill, Embodiment and Moral Critique: A Christian Social Perspective, pp. 407-408.

${ }^{39}$ MW, 45:5.

${ }^{40}$ See Mt. 19:3-8. For a systematic treatment of the structure of John Paul II's catecheses, see M. Waldstein, Introduction in John Paul II, Man and Women He Created Them, M. Waldstein (trans.), Boston, 2006, Pauline Publishers, pp. 106-128.

${ }^{41}$ For a full account of his rejection of utilitarianism, see K. Wojtyła, Love and Responsibility, San Francisco 1993, Ignatius Press, pp. 21-40. 
two creation accounts ${ }^{42}$. Three main themes that emerge from John Paul II's analysis can be helpful in relation to the current argument.

First, John Paul II's reflections strongly presuppose a unity of biological, physical, and moral personhood within one human nature. The corporeal nature of the human being is inseparable from his nature as "person". The notion of "original solitude" presents the human person "alone" in his humanity in all of creation as "in a unique, exclusive, and unrepeatable relationship with God himself", with a subjectivity that characterizes the person ${ }^{43}$. Unlike other animals, the human person is marked with self-consciousness and selfdetermination, which includes the "consciousness of one's body... the discovery of the complexity of one's structure" ${ }^{4}$. Following the Genesis accounts (in this case, the second creation account), humanity is also characterized by "original unity," upon discovery of the "definitive creation" of woman. Unity refers both to the unity of human nature, and to the call to union of man and woman. "The fact that man is a 'body' belongs more deeply to the structure of the personal subject than the fact that in his somatic constitution he is also male or female" ". Man and woman emerge from "the mystery of creation first of all as brother and sister in the same humanity"46. Being a "body" takes precedence and is prior to being instantiated as male or female.

In John Paul II's account, the human being is a body, and does not "have a body", or is not "in a body". Any attempt that would refer to the "many partial conceptions that dwell on one or another aspect of the compositum humanum but do not reach man's integrum or leave it outside the field of vision"47 would not do justice to the scriptural account. What is at stake in

${ }^{42} \mathrm{He}$ recognizes, of course, the insights of historical-critical scholarship that place the accounts in vastly differing contexts and times. Nevertheless, a central assumption that governs his method is the unity of the scriptures in their ability to express the truth about the human condition. See MW, 1-3. For some insights into John Paul II's method of scriptural exegesis, see John Paul II, Address to the Pontifical Biblical Commission, 7 IV 1989.

${ }^{43}$ Ibid., 5:6, 6:2.

${ }^{44}$ Ibid., 6:1, 7:1.

${ }^{45}$ Ibid., 8:1.

${ }^{46}$ Ibid., 18:5. Emphasis added. Notice the similarity between John Paul II's statement "man is a body" and Rudolph Bultmann, For Paul, "the soma is not something that outwardly clings to a man's real self (to his soul, for instance), but belongs to his very essence, so that we can say that man does have a soma; he is a soma". R. Bultmann, Theology of the New Testament, vol. 1, New York, 1951, Scribner's.

${ }^{47}$ Ibid., 23:3. 
John Paul II's affirmation of the human being as a body? Rather than offering a view of the person that emphasizes the soul or spiritual over the material, or which allows the material body to be seen as an "other" or a "part", John Paul II's understanding allows him to place great emphasis on the ability of the body to "speak a language".

This second characteristic of John Paul II's account, in addition to rejecting a split between moral, psychological, and biological personhood and the body, presupposes the body's revelatory power. In his discussion of original unity and nakedness, he draws insights from Gen. 2:23-25. The body, the pope argues, reveals the person. "This concise formula already contains all that human science will be able to say about the structure of the body as an organism, about its vitality, about its sexual physiology, etc. In this first expression of the man, 'flesh from my flesh' contains also a reference to that by which that body is authentically human and thus to that which determines man as a person... a being that is, also in all its bodiliness, 'similar' to God"48. John Paul identifies within the body a "spousal meaning", that is "the power to express love: precisely that love in which the human person becomes gift and - through this gift - fulfills the very meaning of his being and existence"49. The human body, in its structure and nature, reveals the ethical demand placed upon the person to become the gift for another ${ }^{50}$.

In addition to revealing the nature of the relationship that ought to characterize one's stance toward another, the body also reveals something of the nature of God. "The body, in fact, and only the body, is capable of making visible what is invisible: the spiritual and the divine. It has been created to transfer into the visible reality of the world the mystery hidden from eternity in God, and thus to be a sign of it" sacrament", understood as a "sign that efficaciously transmits in the visible

${ }^{48}$ Ibid., 9:3.

${ }^{49}$ Ibid., 15:1.

${ }^{50}$ The "spousal meaning" of the body is therefore not limited to conjugal self-giving through sexual union. The spousal meaning of the body is also lived in the vocation to celibacy, for example, as the celibate person has offered a gift of his or her person to God in order to freely serve others. The "spousal meaning" therefore carries a primary, existential sense that is not bound to or limited in scope by its relation to sexual self-giving. On John Paul II's view, even a single person, not living within the vows of the religious or married life, might still be living the "spousal meaning" revealed by the body through her dedication to her work, her friends, her Church, community, and society if in each of these spheres she enacted self-giving love and dedication to the good of others.

${ }^{51}$ Ibid., 19:4. 
world the mystery hidden from God in eternity... the mystery of Truth and Love, the mystery of divine life, in which man really participates" 52 . Through the sacramental nature of the body one discerns the invitation to participate in the eternal exchange of love between the three persons of the Trinity ${ }^{53}$. The body therefore witnesses to "creation as a fundamental gift... to Love as the source from which this same giving springs" 54 . Gratitude, reverence, and awe characterize the worldview that ought to result from these reflections. The body, in its very materiality, witnesses to the immanent Trinity and the calling to "become partakers of divine nature"

The invitation to participate in the love of the Trinity is made possible by Christ. Thus the third and most fundamental element in this theology of the body, in which the body is recognized as a sacrament that reveals both God, and the human person's true calling to participate in the love of God through self-gift, is its Christocentric and Incarnational basis. One of the most cited sections of the Second Vatican Council in these catecheses is Gaudium et spes, 22. "The truth is that only in the mystery of the incarnate Word does the mystery of man take on light. For Adam, the first man, was a figure of Him Who was to come, namely Christ the Lord. Christ, the final Adam, by the revelation of the mystery of the Father and His love, fully reveals man to man himself and makes his supreme calling clear"s6.

Jesus Christ is the final revelation of the meaning, purpose, and destiny of the human person, including the body. "The fact that theology also includes the body should not astonish or surprise anyone who is conscious of the mystery and reality of the Incarnation. Through the fact that the Word of God became flesh, the body entered theology... through the main door" 57 . Thus, if Christians

52 Ibid.

${ }^{53}$ Traditional theological categories would identify this as perichoresis, or the mutual indwelling of the Father, Son, and Spirit who exist in a relationship of self-giving love to one another. $C f$. St. Augustine, De Trinitate, VIII.10.14.

${ }^{54}$ Ibid., 14:4.

552 Pet. 1:4.

${ }^{56}$ Gaudium et spes, 22.

${ }^{57} \mathrm{MW}, 23: 4$. In this statement, it is clear that John Paul II's understanding of anthropology and Christology has parallels with that of Bernard Häring, C.Ss.R, who writes, "So deep is our conviction that the doctrine about man in moral theology (anthropology) must be studied in the light of Christology that it seems to us to be in a measure an actual part of Christology. Let us note that if we are to understand man who is called by Christ, this is possibly only in light of Him who calls. Our study of man is not just man, but man as created in the Word of the Father, who is 
hold to a robust Chalcedonian Christology of one person-two natures, in which the Second Person of the Trinity, without any loss to itself, took upon itself all that is required of human nature (including the body) and came to authentically express it, Christians cannot denigrate the value of the human body, to which divinity is united in Christ. For John Paul II, this Christocentric affirmation of the value of the human body forms the heart of his method.

The self-giving love of Christ throughout his life, death, and resurrection forms the basis for the call to love as Christ loved. The ethic of love as selfgift therefore results from John Paul II's analysis of Christ's words and the Genesis account. Again referencing the Second Vatican Council, John Paul points out, 'One can understand this 'spousal meaning' of the human body only in the context of the person. The body has a spousal meaning because the human person, as the Council says, is a creature that God willed for its own sake and that, at the same time, cannot fully find himself except through the gift of self. (GS, 24:3)" ${ }^{\prime 58}$.

The spousal meaning of the body, that is, the existential truth that the human person exists for self-giving love, urges one to build a communio personarum on earth, which is itself a reflection of the Trinitarian love of God. A society characterized by such communio would radically counter an understanding of the person in society as an autonomous individual with subjective rights, who must safeguard these from an encroachment upon others, usually through a utilitarian calculation of his own good, or the benefit of the society. The vision given by John Paul II in his catecheses can lead to "solidarity, openness to others, and service to them" 59 and promote the "highest levels of human value and accomplishment, such as love and friendship..." ${ }^{\prime 60}$. The integral vision offered here is that of the "peace of the interior gaze" that is characterized by the "simplicity and fullness of vision in which [an] understanding of the meaning of the body is born from the very heart... of community-communion" $"$.

Christ”. See B. Häring, The Law of Christ, 1:61. As found in K.A. Cahalan, Formed in the Image of Christ: The Sacramental-Moral Theology of Bernard Haring, C.Ss.R, Collegeville, MN, 2004, The Liturgical Press, 2004.

\footnotetext{
${ }^{58}$ Ibid., 15:5.

59 John Paul II, Evangelium Vitae, 19.

${ }^{60}$ L. Cahill, Embodiment and Moral Critique: A Christian Social Perspective,..., p. 405.

${ }^{61}$ Ibid., 13:1.
} 


\section{The Human Body and the Body of Christ}

The understanding of the spousal dimension of the body-person and its sacramentality ought to be fostered in the life of the Church through the theologia prima of the liturgy: as both the "source and the summit of the Christian life," the Church's public proclamation is based on the liturgy as the source of moral formation ${ }^{62}$. If Catholics seek to "do" a Catholic bioethics, they must first take into adequate account the liturgical basis for understanding the body, and therefore the person ${ }^{63}$. The liturgy is the practice par excellence that sustains a proper vision of the body and the person, in relation to the entire order of the cosmos and all of creation, which radically undercuts a utilitarian or technological view that brings with it a desire to dominate, manipulate, and control nature as a result of the notion of "progress," driven by a desire to overcome the human condition. Brent Waters argues that the, "finitude entailed in our status as embodied creatures is not merely an unfortunate limit to be overcome but defines and delineates the normative shape and pattern of human life within the dictates of temporal necessity. Why else would the Word who became flesh share in the most common experiences of birth and death? And why else the need for a crucified reconciler, resurrected savior, and exalted lord as the instrument of creation's vindication and redemption?"

It is within the liturgy that the Word made flesh, Christ the reconciler, savior, and Lord is encountered. Christ, the Word made flesh, sustains, strengthens,

${ }^{62} \mathrm{Cf}$. Lumen Gentium, 11. I borrow the term "theologia prima" from D. Fagerberg, Theologia Prima: What is Liturgical Theology?, Chicago 2004, Hillenbrand Books. While he defines theolgia prima in many ways, perhaps the notion that is most pertinent here is "something that comes at the end of an ascetical journey as an effect of holiness", which requires an understanding of leitourgia as "something more than the thin business of discovering how to creatively use liturgy, banners, and stoles". p. 110. The following discussion will show that a "liturgical theology" concerns those practices and rituals that shape the Christian as a moral agent, whose life is seen to have its origins and end in the Trinitarian God, and whose actions either assist her or disable her from making the entirety of life a "spiritual worship" pleasing and "acceptable to God" (Rom. 12:1).

${ }^{63}$ It is beyond the current argument, of course, to derive specific "norms" for bioethics, or discuss in detail the application of a "liturgical worldview" to the concrete ethical arguments that bioethics faces. Rather, I seek to argue that the liturgical worldview of the Church needs to a priori already order a bioethicist to adopting or rejecting particular views as incompatible with the purpose and destiny of the body-person. The liturgy contains within its rites, structure, and enactment, in texts of prayers, body postures, tangible signs, etc. what ought to motivate the entirety of a Christian bioethicist's discussions.

${ }^{64}$ B. Waters, This Mortal Flesh: Incarnation and Bioethics, Grand Rapids, MI, 2009, Brazos Press, p. 129. 
and forms the Church at her source. As Susan and Gregory Jones point out, "Christian worship provides a site for reclaiming the sense that all of us... are creatures made in the image and likeness of God, destined for communion with God, and worthy of participation in the praise of God"65. The vision of communion based on self-gift offered by John Paul II's theology of the body is sustained and practiced within liturgical worship. Yet, in what sense must "liturgical worship" and a "liturgical worldview" be understood? ${ }^{66}$.

The liturgical nature and vocation of the Church encompasses all other dimensions of the Church's existence and work on earth. "For the liturgy... is the outstanding means whereby the faithful may express in their lives, and manifest to others, the mystery of Christ and the real nature of the true Church"67. The authentic nature of the Church is made manifest through the Church's liturgical rites, of which the Eucharist stands as the "the summit toward which the activity of the Church is directed; at the same time it is the font from which all her power flows" 68 . The Eucharist is "constitutive of the Church's being and activity" ${ }^{\prime 9}$. Orthodox theologian Alexander Schmemann points out that it is precisely in and through her liturgy that "the Church is informed of her cosmic and eschatological vocation, receives the power to fulfill it and thus truly becomes 'what she is' - the sacrament, in Christ, of the new creation; the sacrament, in Christ, of the Kingdom". The liturgy makes the Church the "realm of grace and communion with God, of new knowledge and new life" 70 .

${ }^{65}$ S. Pendleton-Jones and L.G. Jones, Worship, the Eucharist, Baptism, and Aging, in: Growing Old in Christ, S. Hauerwas, C. Bailey Stoneking, K.G. Meador, D. Cloutier (eds.), Grand Rapids, MI, 2003, William B. Eerdmans Publishing Company, p. 187. While the Jones' are not Catholic, the ecumenical nature of liturgical studies in the United States justifies the inclusion of this source, as well as other non-Catholic authors who reflect on the liturgy. Insofar as we are limiting the meaning of "liturgy" to a narrow sense referring to the Catholic Eucharist, then these authors do not refer to the same type of worship. However, if by "liturgy" we mean the public action and worship of Christians (broadly conceived), then such references and arguments will be found helpful for the purposes of this essay.

${ }^{66}$ I do not hope to provide here a comprehensive theology of the Eucharist, but by outlying a basic structure, hope to expand the meaning of "liturgy" to encompass more than just the liturgical rites.

${ }^{67}$ Sacrosanctum concilium, 2.

${ }^{68}$ Ibid., 10.

${ }^{69}$ Pope Benedict XVI, Sacramentum caritatis, 15.

${ }^{70}$ A. Schmemann, Liturgy and Tradition, Thomas Fisch (ed.), Crestwood, NY, 2003, St. Vladimir's Seminary Press, pp. 57-58. 
Within the liturgy, the People of God, forming the Body of Christ, are sanctified "by means of signs perceptible to the senses" Eucharist that we "become one with God, and one with one another; this is how we are re-membered to God, and to one another; this is how the Church becomes the body of Christ" ${ }^{\text {". }}$. The American Catholic ethicist M. Therese Lysaught, in her discussion of the importance of funeral rites for fostering the proper understanding of the body and person, argues, "The rites locate our lives and deaths within the context of Christ's death and resurrection... the resurrection of the body. For Christians, this is... a claim that our bodies are an integral part of who we are. The resurrection affirms that God will raise us to new life. 'Us', - not some disembodied spirits, but the full persons he knew, loved, and saved. It is a claim that God's grace is mediated through the material: in the Incarnation, God became human flesh and dwelt among us; in the Passion, it was Christ's body that was crucified; in the Eucharist, Christ is fully present in the elements of the bread and wine; as we partake of these elements, approaching the altar with our bodies, eating and drinking, we become the very body of Christ; and in the eschaton, it is the very materiality of creation that God will transform and glorify"73.

For this reason, a Eucharistic preface can affirm, "For you so loved the world that in your mercy you sent us the Redeemer, to live like us in all things but sin, so that you might love in us what you loved in your Son"74. It is within the liturgical rites, with the Eucharist at the center, that we "discern ourselves, the church, and the world - indeed all of life and reality - as formed by the Gospel" ". The liturgy forms Catholics to develop a "liturgical worldview," which must be continued outside of the short time during which the community gathers for Eucharistic celebration. "Cult, liturgy in the proper sense, is part of this worship, but so too is life according to the will of God; such a life is

${ }^{71}$ Pius XII, Mediator Dei, 22. See Smith, p. 22.

${ }^{72}$ H.L. Smith, Where Two or Three are Gathered: Liturgy and the Moral Life, Cleveland, $\mathrm{OH}$, 1995, The Pilgrim Press, p. 65.

${ }^{73}$ M.T. Lysaught, Memory, Funerals, and the Communion of Saints: Growing Old and Practices of Remembering, in: Growing Old in Christ, p. 286.

${ }^{74}$ See the "Roman Missal", Preface for Sundays of the Year, VII.

${ }^{75}$ H.L. Smith, Where Two or Three are Gathered: Liturgy and the Moral Life, Cleveland, OH, 1995, The Pilgrim Press, p. 70. Jones and Jones make a very similar point, "We learn through worship, through prayer and praise of God, that our identity as persons and our hope for the future are shaped by God's memory and hope manifested in Jesus Christ", pp. 195-196. 
an indispensible part of true worship... is the very life of man, man himself as living righteously"76.

During the opening of the Pauline Year, Benedict XVI prayed that all Christians might "become true liturgists of Jesus Christ" 77 . He sees in Romans 12 an understanding of the cosmic dimension of the liturgical worldview. Paul "knows he is called... in the priestly service of the Gospel of God, so that the offering of the Gentiles may be acceptable, sanctified by the Holy Spirit." Paul's daily hardships, toils, suffering, and joys are all means by which he offers his life and the life of those whom he serves to God in an act of liturgical worship. "When the world in all its parts has become a liturgy of God, when, in its reality, it has become adoration, then it will have reached its goal and will be safe and sound" 78 .

It is necessary to re-acquire a liturgical worldview in order not only that the Eucharist might be understood at the center of the Church, but also at the center and heart of each individual's life and action. If this worldview is recovered, then "Christianity's new worship [will] include and transfigure every aspect of life" "I9 . In a field characterized by instrumental and technocratic reason and ambivalence about the notion of the person, it is necessary to gain an integrated understanding of the human person and its relation to God, the Church, and the world. "The worship of God in our lives cannot be relegated to something private and individual, but tends by its nature to permeate every aspect of our existence. Worship pleasing to God thus becomes a new way of living our whole life, each particular moment of which is lifted up, since it is lived as part of a relationship with Christ and as an offering to God" $"$

Thus, in order to understand the vocation of the Catholic bioethicist as a participation in and particular manifestation of the Church's role in offering worship to God, worship must be understood as more than simply a liturgical rite. Rather, a liturgical worldview regards concrete human decisions and the moral life. It presupposes an understanding of the human being as part of the created world, and yet not "of it." Ratzinger argues that "we have to

${ }^{76}$ J. Ratzinger, Spirit of the Liturgy, San Francisco 2000, Ignatius Press, p. 17.

${ }^{77}$ Pope Benedict XVI, Homily for the Feast of Sts. Peter and Paul, 29 VI, 2008. Presumably, this would include Christian bioethicists.

${ }^{78}$ Ibid.

${ }^{79}$ Pope Benedict XVI, Sacramentum caritatis, 70.

${ }^{80}$ Ibid., 71. 
recapture this cosmic vision if we want once again to understand and live Christianity in its full breadth" ${ }^{\prime 1}$. Catholics must recapture a vision of created reality as a gratuitous gift from God, and of the human person, in particular, as a microcosm of the universe ${ }^{82}$. Humanity exists in relation to the cosmos, and yet belongs especially to God through the call to communion with, and in imitation of, the self-giving love of the Trinity, a God who creates, redeems, and sanctifies. Indeed, "true liturgical action is the deed of God, and for this very reason the liturgy of faith always reaches beyond the cultic act into everyday life, which must itself become liturgical, a 'service' for the transformation of the world" $"$. The liturgical life must be a life in the Spirit, which recognizes the action of God and the response of the human person.

In a particular way, the liturgy and the resulting liturgical worldview trains Catholics to see their bodies and persons as "temples of the Holy Spirit" ${ }^{84}$. Sr. Mary Timothy Prokes points out, "This underscores the extraordinary dignity of the human body as a sacred place of worship, although it may be desecrated from within or without. For those who are united to Christ in the Holy Spirit, the body is a living, mobile location of prayer, a living monstrance of Christ" $" 85$. Prokes draws upon Teilhard de Chardin to show that "our bodies are not part of the universe that we possess totally, but the whole of the universe that we possess partially," and therefore one who is aware of this relation of the body to the universe is able to "bring the entire universe to praise" $"$. The Catholic, who understands her body as part of a universe that has been redeemed by Christ and His body, and continues to be sustained by the body of Christ, the Church, recognizes the necessity of "praying the body".

To "pray the body" presupposes its goodness, worthiness to be offered and acceptability to God as a means by which God is adored and praised. "To "pray the body' requires a prior capacity to receive embodiment as a gift of love. The 'prayed body' integrates reverence, a sacred freedom (which ascetical theology has traditionally called 'detachment,') and the offering of the embodied self as

${ }^{81}$ J. Ratzinger, Spirit of the Liturgy, San Francisco 2000, Ignatius Press, p. 101.

${ }^{82}$ Such a notion is present in many of the Church Fathers, particularly Maximus the Confessor. See A. Louth, Maximus the Confessor, London 1998, Routeledge, pp. 61-63.

${ }^{83}$ Ibid., p. 175.

${ }^{84} 1$ Cor. 6:19. Cf. M.T. Prokes, Toward a Theology of the Body, Grand Rapids, 1996, Eerdmans, p. 135.

${ }^{85}$ Ibid., p. 135.

${ }^{86}$ M.T. Prokes, Toward a Theology of the Body, Grand Rapids, 1996, Eerdmans, p. 136. 
gift" $"$. The ability for the Catholic to "pray the body" and offer the embodied self as gift is based on Christ's Paschal self-offering, continued in the liturgy. "Christ's personal self-gift in the body and blood is the prime reference for understanding every human potential for bodily self-gift" 88 . Paul encourages the early Christian communities to pray always and without ceasing ${ }^{89}$. This "extension of liturgical prayer in home and marketplace takes it meaning from the same source - body as expression of self-gift" $"$.

The Catholic liturgical view of the body therefore counters any "worshipful attitude which... treats the earth as the ultimate reality," and also stands firmly against a "utilitarian perspective, extending scientific/technical ingenuity to the re-creation of the earth and its inhabitants according to the insights of the present age" 91 . Leitourgia, both in its cultic sense and its broad sense, provides the practice par excellence that sustains a theology of the body that proposes the human body-person as a revelatory gift from God, while at the same time seeking to understand the truth of personhood considered integrally and adequately. Thus, D.B. Hart, a non-Catholic theologian, even comments that John Paul II's theology of the body is a "monument to the grandeur and fullness of [Christian] 'total humanism", a reminder of "how vast the Christian understanding of humanity's nature and destiny is," and an inspiration to reject any "philosophy, ethics, or science that would reduce human life to an instrumental moment within some larger design"92.

\section{Liturgical Worldview in Practice}

The question remains: how does this theological understanding of the body, sustained in the liturgical practices and liturgical worldview of the community and Church, affect the Catholic bioethicist? It is necessary to recall the twofold task of the Catholic bioethicist, and relate it to several modest proposals. First, she must be Catholic, which means that she must draw from, develop,

\footnotetext{
${ }^{87}$ Ibid., p. 137.

${ }^{88}$ Ibid., p. 144.

${ }^{89}$ Cf. Col. 1:3; Col. 4:2; 1 Thess. 1:2; 1 Thess. 5:17; 2 Tim. 1:3.

${ }^{90}$ Prokes., p. 145.

${ }^{91}$ Ibid.

${ }^{92}$ D.B. Hart, The Anti-Theology of the Body, The New Atlantis (Summer 2005), p. 73.
} 
and immerse herself more deeply in the theological inquiries and liturgical life of the Church, in order not to lose sight of the great value of the person, including the affirmation of the body, which is missing from many of the contemporary personhood debates, as we have noted in the beginning of this article. This task itself requires intellectual and doctrinal formation, as well as liturgical and sacramental participation. While it is a minimal requirement to "intellectually value" the corporeal person for the sake of articulating philosophical positions, it is much harder to live out the calling of human corporality, being created out of love and for love, and called to participate in the divine life. This calling is upheld through the texts of the liturgy, the central feast days of the liturgical calendar, the commemorations of saints, and the various ascetical practices associated closely with particular seasons ${ }^{93}$. Thus, the Catholic bioethicist, who usually dwells in a very specialized and often secular discipline, will be immersed in and draw from the wellsprings of the worldview embodied in the living communion of the Church.

In addition, this liturgical worldview ought to be fostered through catechetical formation, particularly through an understanding of the rites, seasons, language, types, symbols and gestures themselves. The formation of such a worldview can begin in the family that is a basic instantiation of the communio personarum to which society is called. "The Christian family constitutes a specific revelation and realization of ecclesial communion, and for this reason too it can and should be called 'the domestic Church"'94. Parents ought to educate and form children from a young age about the value and

${ }^{93}$ After all, aren't some of the central Christian feasts about the body: the Annunciation and Incarnation of Christ, the Nativity, the Bodily Resurrection, the Ascension, the Assumption, and the Immaculate Conception? Each of these central feasts in the Catholic liturgical calendar depends on the body. Saints, in particular, the martyrs, remind the Church of the powerful witness made by offering one's body unto death out of love for God, the Church, or moral truths. Ascetical practices such as fasting are not masochistic denigrations of the body, but hinge upon a unity of the integrated person: it is precisely through fasting, a bodily practice, that one can grow in greater spiritual union with Christ, develop habits of detachment and temperance, and grow in love for one's neighbor, particularly the poor or suffering. Tertullian shows beautifully how the liturgical rites of the Church uphold the integrity of the Christian vision: "To such a degree is the flesh the pivot of salvation, that since by it the soul becomes linked with God, it is the flesh which makes possible the soul's election by God. For example, the flesh is washed that the soul may be made spotless: the flesh is anointed that the soul may be consecrated: the flesh is signed $<$ with the cross $>$ that the soul too may be protected: the flesh is overshadowed by the imposition of the hand that the soul may be illumined by the Spirit: the flesh feeds on the Body and Blood of Christ so that the soul also may be replete with God". See De Resurrectione, E. Evans (ed.), London 1960: S.P.C.K.

94 John Paul II, Familiaris Consortio, 21. 
goodness of creation and the body. Outside the communion of the family, such formation ought to be undertaken by pastors and lay ministers during heightened times of interaction with parishioners, such as marriage preparation programs, funerals, baptismal preparations, and confirmation classes ${ }^{95}$.

Secondly, having allowed herself to be formed by the liturgical practices and worldview of the Church, the task of the Catholic bioethicist is to develop a vocabulary, concepts, logic, and philosophy that is capable of engaging the field of bioethics and medicine in a manner that does not sacrifice fundamental Catholic commitments to the "total humanism" of this vision, while at the same time being able to articulate positions which might appeal to those who are outside of the Church, as is increasingly the reality in bioethics today ${ }^{96}$. In addition to dialogue with secular philosophers and ethicists, it would be fruitful for the Catholic bioethicist to carry on discourse with liturgical theologians who are both Catholic and non-Catholic Christians. As Smith notes, to "suggest that [ethics and liturgy] are autonomous, independent, separable entities which now, by some contrivance, need to be or can be brought into some sort of relation" is based on the presupposition that the two branches of theology are not related. However, "prayer, proclamation, baptism, eucharist, offering, intercession all of these and more are moral acts because they display the kind of people we are"97. While recognizing the importance of "specializations" in theology and ethics, it is also important therefore to recognize that all these branches of theology are in pursuit of understanding and articulating the truth, which finds its origin in the same source. Of course liturgical scholars will not usually write about feeding tubes and cloning, and bioethicists will not write about the Eucharist, but shouldn't those who write about human life maintain dialogue with those who study the "source and summit" of the Christian life?

Liturgical scholars can remind bioethicists of the liturgy as the moral locus of formation, and the importance of a "liturgical life". They need to remind

${ }^{95}$ Sacramental formation is an ideal time during which to elucidate the dignity of the body. Tangible signs are used (bread, wine, water, rings, oil, chrism, etc.) and actions are performed upon or by a body (immersion, imposition, reception, anointing, etc.) in order to effect a spiritual, invisible reality.

96 The articulation of a philosophy and categories that might remain faithful to the Christian vision presented here, and appeal to a secular audience, is of course beyond the scope of this paper. One such attempt is made by M.F. Rousseau, Deriving Bioethical Norms from the Theology of the Body, in: National Catholic Bioethics Quarterly, (Spring 2003): pp. 59-67.

${ }^{97}$ H.L. Smith, Where Two or Three are Gathered: Liturgy and the Moral Life, Cleveland, $\mathrm{OH}$, 1995, The Pilgrim Press, p. 37. 
and invite bioethicists, whose field can often be dominated by the paradigmatic discourses of secularity, that the Church's vision has much to contribute. Since much bioethical discourse revolves around "cases" and disputed questions, or challenges in light of new developments in technology and science, without losing sight of the importance of these questions, the Catholic bioethicist must nevertheless bring the liturgical vision of the human person to bear on fundamental questions, such as personhood and the truth and meaning of human life ${ }^{98}$. Bioethicists, on the other hand, can help liturgical scholars see the importance of their work outside their intra-ecclesial discipline. A Catholic bioethicist, the heart of whose work is formed in a liturgical view that seeks to promote a vision of the person, integrally and adequately considered, provides a concrete example of how the work of liturgical scholars can contribute to the formation of those outside their field. Liturgical scholars, rather than simply focusing on historical studies about the development of rites, will recognize what is at stake in being formed by the Church's liturgy, and will remember that they ought to provide the "grammar" for those, such as bioethicists, whose job will be to use that grammar to develop a language to promote the vision sustained in and through the Church into their increasingly secular fields.

While these proposals are modest, and do not offer definitive solutions to often complex discussions in bioethics, they uphold a commitment to the fundamental affirmation of the human body and the integral consideration of the person within the Christian community, and specifically that account offered by John Paul II's catecheses on the theology of the body. These proposals can serve as a basis for a fruitful and necessary beginning for the Catholic bioethicist to bring about the solidarity, openness to others and service to them that remains as a fundamental commitment in many of the problems medical and bioethics faces today. It is a reminder that, prior to answering the question of "what kind of bioethicist shall I be", the Catholic bioethicist must first answer the question, "What kind of Catholic shall I be"?

${ }^{98}$ The state of much bioethical debate today can be summarized by A. Smith-Iltis: "Bioethics is not about theory. Bioethics cannot be about theory because there is no universally agreed upon and recognized theory of right and wrong." Smith-Iltis, A., Bioethics as Methodological Case Resolution: Specification, Specified Principlism and Casuistry, Journal of Medicine and Philosophy, 25, No. 3, p. 272. It is precisely against such an assessment of the state of affairs that the Catholic bioethicist ought to enter into dialogue in order to show the ever-present importance of answers to precisely such questions as truth, objective value and meaning, and method. 


\section{Bibliography}

Ashley OP, B., Theologies of the Body: Humanist and Christian, Braintree, MA, 1985, The Pope John Center.

Benedict XVI, Homily for the Feast of Sts. Peter and Paul, 29 VI 2008, Vatican City, http://www.vatican.va/holy_father/benedict_xvi/homilies/2008/documents/hf_benxvi_hom_20080629_pallio_en.html (24 IV 2013).

Benedict XVI, Sacramentum Caritatis, Vatican City, 2007, Libreria Editrice Vaticana.

Brown P., The Body in Society: Men, Women, and Sexual Renunciation in Early Christianity, New York 1988, Columbia University Press.

Bultmann R., Theology of the New Testament, vol. 1. New York 1951, Scribner's.

Cahalan Kathleen A., Formed in the Image of Christ: The Sacramental-Moral Theology of Bernard Haring, C.Ss.R. Collegeville, MN, 2004, The Liturgical Press.

Cahill Lisa and M. Farley, Embodiment, Morality, and Medicine, Dordrecht 1995, Kluwer Academic Publishers.

Lauritzen P. (ed.), Cloning and the Future of Human Embryo Research, Oxford 2001, Oxford University Press.

Dworkin R., Life's Dominion, New York 1993, Alfred A. Knopf.

Fagerberg, D., Virgil Michel on Liturgy and Social Justice: A New Appraisal, "Chicago Studies", Vol. 48, No. 3 (Autumn/Winter 2009).

Fagerberg D., Theologia Prima: What is Liturgical Theology?, Chicago 2004, Hillenbrand Books.

Fletcher J., Four Indicators of Humanhood-The Enquiry Matures, "Hastings Center Report" Vol. 4, No. 6 (1975), p. 4-7.

Hauerwas S., Bailer C., Stoneking, Meador K.G., Cloutier D. (eds.), Growing Old in Christ, Grand Rapids, MI, 2003, William B. Eerdmans Publishing Company.

Hart DB., The Anti-Theology of the Body, "The New Atlantis" (Summer 2005), p. 64-73.

Jenson RW., Reading the Body, "The New Atlantis" (Summer 2005), p. 73-82.

John Paul II, Man and Women He Created Them, Boston 2006, Pauline Publishers.

John Paul II, Evangelium Vitae, Boston 1995, Pauline Publishers.

Prokes MT., Toward a Theology of the Body, Grand Rapids, MI, 1996, Eerdmans.

May W., Bioethics and Theology: How are they Related?, conference paper at "Congresso per la Federazione Dei Centri Internazionali di Inspiratione Personalista", 9-10 VI 2003.

McKenny G., To Relieve the Human Condition: Bioethics, Medicine, and the Body, Albany 1997, SUNY Press.

Meilaender GC., Body, Soul, and Bioethics, Notre Dame, IN, 1995, University of Notre Dame Press.

Michel, O.S.B., V., The Liturgy as the Basis of Social Regeneration, "Orate Fratres" 9 (1935), p. 536-545.

Lammers S., Verhey A.(eds.), On Moral Medicine, Grand Rapids, MI, 1998, William Eerdmans Publishing Company.

Ratzinger J., Spirit of the Liturgy, San Francisco 2000, Ignatius Press. 
Rousseau MF., Deriving Bioethical Norms from the Theology of the Body, "National Catholic Bioethics Quarterly" (Spring 2003), p. 59-67.

Saliers D., Anderson E.B., Morrill B. (eds.), Liturgy and the Moral Self. Humanity at Full Stretch Before God: Essays in Honor of Donald E. Saliers, Collegeville, MN, 1998, Pueblo.

Schmemann A., Liturgy and Tradition, T. Fisch (ed.), Crestwood, NY, 2003, St. Vladimir's Seminary Press.

Smith HL., Where Two or Three are Gathered: Liturgy and the Moral Life, Cleveland, OH, 1995, The Pilgrim Press.

Vatican Council II, A. Flannery (ed.), New York 1998, Costello Publishing Company.

Waters B., This Mortal Flesh: Incarnation and Bioethics, Grand Rapids, MI, 2009, Brazos Press.

Wojtyła K., Love and Responsibility, HT Willetts (trans. and ed.), San Francisco 1993, Ignatius Press. 